\title{
A Study of Chinese College English Teachers' Feedback Problems in English Writing Teaching
}

\author{
Yurong Huang \\ Foreign Languages Teaching Department \\ Beijing Institute of Graphic Communication \\ Beijing, China 102600
}

\begin{abstract}
English writing has been regarded as a bottleneck to constrain the effect of college English teaching in China. Aiming at Chinese students' writing problems, Chinese teachers' feedback problems related to students' writing correction have been analyzed. Then based on teachers' changing of teaching concept and attaching great importance on output, the flexible, punctual, continuous and targeting multi-mode feedback under the blended teaching model has been put forward to help to improve students' writing ability and overall effect of college English teaching.
\end{abstract}

\section{Keywords—writing; feedback; college English teaching}

\section{INTRODUCTION}

With the development of computer science, the popularity of internet and the widespread application of mobile terminals, our country has stepped into the Age of Big Data, and it has influenced people's study method, cognitive style, communication method, and even the whole education ecosystem, of which college English writing is the first to be affected.

English writing is one of the four basic language skills, requiring the writer to express his or her thoughts explicitly and integrally based on his or her cognition. As a practical output skill, writing can express language learner's English ability. However, lots of English learners' writing ability does not look good with such problems as absent-minded writing process, incompact text structure as well as the vague main idea and the like rising constantly due to the long-term teaching method of emphasizing language learners' input and meanwhile ignoring their output in China, which has seriously influenced college English teaching effect. Among all the teaching strategies to help learners improve their writing ability, teachers' feedback seems more important.

\section{LITERATURE REVIEW}

Feedback is a concept in the cybernetics, referring to the process of sending the information out by the control system and reverting it back with the action outcome, according to which the biased error is constantly corrected and the new influence to the succeeding sending will occur again. The purpose of this process is to realize the planned goal with the help of controlling. During the course of English writing teaching, the correction feedback means the readers provide the input information for the writers, based on which the writers can correct their writing on their own[1]. It is an important teaching means given by teachers to their students to improve their writing ability, and meanwhile an indispensable part for an integrated English writing teaching. The effective feedback can help students better polish their expression; make the structure clearer and the thoughts more vivid.

There are various kinds of feedback according to different assessment standards, such as content and context feedback and language expression feedback based on the assessment object; direct feedback and indirect feedback based on the form; self-assessment, peer feedback, teacher feedback as well as online feedback. Researchers found that students count on their teachers' feedback most, and teacher feedback is in dominant position [2]. Students give the greatest expectation to teacher feedback for its flexible instruction and authority. Therefore, teacher feedback is of great importance in students' writing process.

\section{FEEDBACK PROBLEMS IN COLLEGE ENGLISH WRITING IN CHINA}

Writing is the most essential measure to test language learners' language ability. However, among the four basic listening, speaking, reading and writing skills, writing is the weakest one, [3] and students' writing ability stands still constantly without obvious improvement [4]. This result can be attributed to various reasons, among which are problems of English teachers' feedback. This article aims to do some analysis and exploration based on these problems and has summarized them as follows:

\section{A. Teachers Have Not Attached Enough Importance to Feedback}

Great importance has been attached to input ignoring the learners' output in college English teaching in China. This curriculum setting resulted in teachers focusing on reading and listening, especially reading. They believe students will acquire the writing skills with the help of teachers' analyzing the text, explaining the vocabulary and some sentences. Therefore, there is no enough emphasis given to writing, and some schools do not even have an integrated set of English wring teaching plan. Even though there is the teaching plan, English teachers' teaching focus has only been put on the 
skills of writing sentences and paragraphs, ignoring the output practice of writing skill. Without enough writing activities, the feedback will be neglected, let alone its function of helping learners to improve their ability. Over time, there is a lack of enough communication between teachers and students, finally influencing students' writing interest.

\section{B. Teachers' Feedback Legs Behind Teaching Task}

Currently, the college English teaching in our country has adopted the model of blending teaching combining the traditional teaching and multimedia teaching based on the information technology. In English writing teaching process, the problems of feedback legging behind the teaching task occur frequently. The reasons include: Firstly, the class size is too large. According to Guide to College English Teaching in 2014 in China, colleges should control the class capacity within 35 students each class in order to effectively cultivate students' speaking and writing output ability. In practice, however, the class size in many universities is too large with more than 30 students at least and even up to 70 which is suitable for reading instead of speaking and writing. For the writing in particular, it's hard for teachers to fulfill the heavy task of feedback in short time. Secondly, the teaching task is too heavy for college English teachers. Many college teachers undertake the teaching task of teaching listening, speaking, reading and writing in one term, so they hardly have enough time and energy to give attention to all the courses. As a result, English writing has to be assigned to students as assignment, and teachers only check it, impossibly providing students with timely and targeted feedback.

\section{Teachers' Feedback is Too Simple}

Under the blending teaching model, English writing teachers should adopt both the traditional writing correction feedback and the online feedback. However, lots of teachers are lack of the ability of accepting and grasping the webbased, digitized and intellectualized teaching reform, hardly adapting to all kinds of newly developed digital writing systems. The digital writing systems based on computer information technology have been widespread in college teaching, therefore if teachers cannot grasp modernized information technology quickly and not be familiar with functions of newly-born smart writing systems, their correction feedback will finally be lack of flexibility and variety which will further badly influence the learners' writing interest.

\section{THE EXPLORATION OF COLLEGE ENGLISH TEACHERS' TARGETED CORRECTIVE FEEDBACK MODEL}

Corrective feedback is an indispensable teaching step for an integrated writing process, and an effective strategy to help writers to improve their writing ability. Focusing on the various problems of teachers' corrective feedback mentioned before, college English teachers' multi-mode and targeted corrective feedback model is discussed here to give some enlightenment.

\section{A. Change the Teaching Concept and Attach Much Weight to Language Output}

According to Guide to College English Teaching in 2014 in China, the cultivation goal of college English course is to improve students' language application ability, namely the ability of communication in English including speaking and writing.

Speaking and writing are two important language output skills for learners. Wang Shouren maintains that English speaking is essential, yet writing is comparatively more important for some special occasion during communication [5]. Wang Haixiao said the teaching goal of college English should be the language application, attaching the great importance to output and use [6]. Therefore, college English teachers should firstly transform teaching concept, giving up the traditional teaching habit and strategy of thinking much of input while neglecting the output and give more weight to cultivation of language output ability based on enough input. During teaching, English teachers should encourage students to do more writing practice and give them targeted and diagnosed correction feedback. The combination of teachers' targeted feedback and students' repeating writing practice can form the positive circulation, helping to better students' writing ability.

\section{B. Emphasize Feedback and Do It in Time with Constancy}

Corrective feedback can not only help students refine the text, broaden their idea but also help teachers to know students' learning method and strategy and assess their learning trend, encouraging the mutual understanding and exchanges between teachers and students and securing their communication. The writing teaching without feedback is an incomplete and mono-directional teacher-centered teaching activity. However, the teaching process should be learningcentered bidirectional activity between teacher and student, so there are various means for their interactive communication, among which is teachers' feedback.

Effective correction feedback should be done in time and keep constant. To begin with, feedback should be given to students in time. This has something to do with students' confidence, positively impact their emotion, and further influence students' self-efficiency. Self-efficiency refers to students' judge and cognition for their ability to finish one task or activity, and the degree of their confidence to judge whether they will be competent in one activity or not. Teachers' feedback in time will naturally influence students' emotion, bringing them high self-efficiency, and students' will also attach more importance to teachers' feedback, which will help to form positive talking system. Secondly, feedback should keep constant. Without constancy, students will neglect their writing, negatively influencing their selfefficiency and the talking system between teachers and them.

\section{Grasp the Information Technology and Make Feedback Flexible and Various}

At present, many teaching platforms spring up. In terms of writing, such digital writing systems as Juku, iwrite, ismart-TRP have been put into use, which impact English 
teachers' teaching concept, teaching method and the like. Teachers should adapt to these impacts and do as follows:

Firstly, change the traditional teaching concept, increase awareness of information and technology and grasp its knowledge and skills, and effectively make well use of the digital writing system. It is well-known that the English teaching reform based on the information and technology is the unstoppable trend, therefore English teachers have to adapt to it from concept to behaviour. Teachers should keep pace with times to be familiar with the digital writing system in their schools, and change the simple feedback since there is no limitation of time and space for web-based digital system.

Secondly, teacher feedback should be done in time with flexibility and variety. Different from teacher-centered traditional teaching, in student-centered teaching concept, teachers play an extremely important role as the manager of the teaching activity and director of students' learning, therefore as the designer of the teaching process, teachers should quit the simple feedback and try to give flexible and various feedback as the following aspects:

We should combine the form-focused feedback and content-focused feedback. The former refers to teachers' feedback to such surface-level errors as grammatical, spelling, punctuation mark, case matching and number mistakes in students' writing. The later refers to teachers' feedback about discourse-level errors such as textual structure, semantic expression, main idea etc. Most teachers in China prefer the former, yet the combination of these two feedbacks is beneficial for students' improvement in their writing process.

We should combine the direct feedback and indirect feedback. Direct feedback means teacher points out clearly students' mistake and tells them the right form, therefore the feedback is clearly written in students' writing. Yet in indirect feedback, teacher does not tell students their mistakes clearly, instead teacher will underline some mistakes in students' writings and students have to analyze and conclude the right forms by themselves. Some scholar found students with poorer English level will prefer direct feedback, yet those with high English ability favor indirect feedback [7].Therefore, teacher can give one of these two feedbacks according to students' English level to individualize it.

We should combine the written feedback with online feedback. The former refers to teacher feedback for students' compositions written on paper, while the latter is the webbased feedback. Because of college English teaching limitation, the class size is usually large and learners mainly from different places all over China with different English levels, so it is of great difficulty for teachers to finish the written feedback in a short time, while there is no time and space limitation for web-based feedback with features of flexibility, individualization and convenience. It is obvious that teacher can combine online and offline feedback to achieve the ideal teaching effect under the blended English teaching model.
Moreover, the smart digital English writing systems should be used scientifically, avoiding excessively depending on it. With the widespread popularization and development of modern information and technology, mobile and real-time online feedback fully meets students' need to receive it anywhere and anytime. However, teacher and student are playing dominant role during teaching and learning and this will not change no matter how fast the modern information and technology develops. The application of information and technology should not fell into "technology only", laying aside the beneficial teacherstudent face-to-face communication in language teaching. In terms of feedback, on the one hand teacher can make well use of the smart digital writing system to correct some superficial language errors, avoiding some repetitive and mechanical text reading. On the other hand, teacher cannot fully count on the English writing system since it hardly helps to spot the deeper mistakes in the writing, so teachers should not regard purely feedback by the writing system as their own feedback.

\section{CONCLUSION}

As an important language output skill, students' English writing ability will be influenced by teachers' feedback to some degree. Under the blended English teaching model in Age of Big Data, college English teachers have to overcome the problems of large class size, heavy teaching task and so on to transform the teaching concept, and adjust their feedback forms according to students' English levels, providing them flexible, diagnosed and targeted feedback constantly and timely to help students to better their writing ability to an ideal level.

\section{REFERENCES}

[1] Keh, C.L. Feedback in the writing process: A model and methods for implementation [J] ELT Journal, 1990, (4): 294-394.

[2] Zhou Yishu. A Comparative Study of Feedback Methods in College English Writing [J] Foreign Language World, 2013, (3): 91.

[3] Huang Yuanshen. Good composition is "written" out - the second talk about English teaching [J] Foreign Language World, 2000, (5): 13-16.

[4] Li Sen. Important measure to improve teaching of English writing: process teaching method [J] Foreign Language World, 2000, (1): 1923.

[5] Wang Shouren. Some Thoughts on College English Teaching in China [J] Foreign Language Teaching in Theory and Practice, 2011, (1): $1-5$.

[6] Wang Haixiao.Reform in the Teaching of College English Writing in the Big Data Era [J] Foreign Language Education, 2014, (3): 66.

[7] Yu Xuelin. An Empirical Study on Effects of Teacher Feedback on Vocational College Students' Writing [D] Nan Chang: School of Foreign Languages of Nan Chang University, Master's thesis, 2010. 